\title{
IMPLEMENTASI MODEL PEMBELAJARAN MISSOURI MATHEMATICS PROJ ECT DALAM UPAYA MENINGKATKAN KEMAMPUAN PEMECAHAN MASALAH MATEMATIS DAN SELF- CONFIDENCE SISWA MADRASAH TSANAWIYAH
}

\author{
Anwar Sadat, M.Pd \\ Jurusan Pendidikan Matematika STKIP Subang \\ mocsadatanwar@gmail.com
}

\begin{abstract}
This study aimed to examine the differences in the increase in mathematical problem solving ability and self-confidence among the students who received the Missouri model study Mathematics Project (MMP) and who obtain conventional learning. In addition, also revealed a correlation between mathematical problem solving ability and self-confidence, well graders graders MMP or conventional. Type of research is quasi-experimental research with the study sample consisted of 75 students of class IX are derived from two classes at MTs Subang. Both classes are given pretest and posttest mathematical problem solving ability, and were given a questionnaire beginning and end of the questionnaire selfconfidence. The research hypotheses were tested with parametric test (t test and Pearson Product Moment Correlation) and non-parametric test (Mann Whitney test). The study states that: (1) increase the ability of students' mathematical problem solving experimental class is better than the control class; (2) an increase in self-confidence grade students experiment better than the control class; (3) there is a positive correlation between mathematical problem solving ability and self-confidence of students, good students experimental class and control class.
\end{abstract}

Keywords: Missouri Mathematics Project, mathematical problem solving, and selfconfidence.

\begin{abstract}
ABSTRAK
Penelitian ini bertujuan untuk menelaah perbedaan peningkatan kemampuan pemecahan masalah matematis dan self-confidence antara siswa yang memperoleh pembelajaran model Missouri Mathematics Project (MMP) dan yang memperoleh pembelajaran konvensional. Selain itu, diungkap pula korelasi antara kemampuan pemecahan masalah matematis dan self-confidence, baik siswa kelas MMP maupun siswa kelas konvensional. Jenis penelitian yang dilakukan adalah penelitian kuasi eksperimen dengan sampel penelitian terdiri dari 75 siswa kelas IX yang berasal dari dua kelas di MTs Negeri I Subang. Kedua kelas diberikan pretes dan postes kemampuan pemecahan masalah matematis, dan diberi angket awal dan angket akhir self-confidence. Hipotesis penelitian diuji dengan uji parametrik (uji t dan uji korelasi Product Moment Pearson) dan uji non parametrik (uji Mann Whitney). Hasil penelitian menyatakan bahwa: (1) peningkatan kemampuan pemecahan masalah matematis siswa kelas eksperimen lebih baik daripada siswa kelas kontrol; (2) peningkatan self-confidence siswa kelas ekperimen lebih baik daripada siswa kelas kontrol; (3) terdapat korelasi yang
\end{abstract}




\section{Didaktik : J urnal Pendidikan Guru Sekolah Dasar, ISSN : 2477-5673 \\ Sekolah Tinggi Keguruan dan IImu Pendidikan Subang \\ Volume II Nomor 1, Desember 2016}

positif antara kemampuan pemecahan masalah matematis dan self-confidence siswa, baik siswa kelas eksperimen maupun siswa kelas kontrol.

Kata kunci: Missouri Mathematics Project, pemecahan masalah matematis, dan self-confidence.

\section{A. PENDAHULUAN}

Pada hakikatnya matematika adalah ilmu yang sering dijumpai dalam kehidupan sehari-hari. Matematika merupakan sarana yang sangat penting untuk meningkatkan kemampuan berhitung dan keterampilan intelektual. Matematika juga merupakan ilmu yang mendasari perkembangan teknologi moderen, mempunyai peran penting dalam perkembangan berbagai disiplin ilmu dan kemampuan daya pikir manusia.

Demi menguasai dan menciptakan kemajuan ilmu dan teknologi dimasa depan, diperlukan penguasaan matematika yang kuat sejak dini, sehingga, matematika merupakan mata pelajaran yang wajib diberikan kepada peserta didik mulai dari jenjang sekolah dasar hingga sekolah menengah atas. Tujuan utama belajar matematika adalah memberikan bekal kemampuan-kemampuan yang sangat diperlukan peserta didik, untuk digunakan dalam kehidupannya sehari-hari.

$\begin{array}{ccc}\text { Salah } & \text { satu } & \text { tujuan } \\ \text { pembelajaran } & \text { matematika yang }\end{array}$
terdapat dalam KTSP matematika 2006 adalah kemampuan pemecahan masalah matematis. Hal ini sejalan dengan pendapat Branca (Sumarmo, 1994) yang mengatakan bahwa pemecahan masalah matematik merupakan hal yang sangat penting sehingga menjadi tujuan umum pengajaran matematika, bahkan bisa dikatakan sebagai jantungnya matematika. Pendapat serupa dikemukakan oleh Wahyudin (2008) bahwa pemecahan masalah adalah bagian integral dari belajar matematika, yang didalamnya harus melibatkan banyak aspek, yaitu: (1) Penalaran dan pembuktian; Komunikasi; (3) Koneksi; dan (4) Representasi matematis.

Selain

kemampuan pemecahan masalah matematis sebagai aspek kognitif, yang dijadikan tujuan utama dalam pembelajaran matematika adalah aspek afekatif, yaitu rasa percaya diri (self-confidence) dalam belajar 
matematika. Self-confidence adalah pandangan atau perasaan positif seseorang terhadap dirinya dan keyakinannya atas pengetahuan, kemampuan dan kapasitas dirinya untuk bisa menjalankan tugas atau menangani persoalan-persoalan hidupnya dengan hasil yang sangat baik.

Pentingnya menumbuhkan rasa percaya diri dalam menjalani kehidupan, seperti dikemukakan oleh Perry (2006), bahwa kepercayaan diri merupakan kunci vital untuk meraih kesuksesan dalam kehidupan pribadi dan pekerjaan. Tanpa adanya rasa percaya diri, tantangan hidup akan terasa sulit untuk diatasi dan masalah-masalah akan sangat sulit untuk bisa dipecahkan.

Beberapa pendapat di atas menunjukkan bahwa antara kemampuan pemecahan masalah matematis dan self-confidence merupakan dua hal yang saling mempengaruhi. self-confidence menjadikan siswa mampu mengatasi tantangan baru dan menyelesaikan pemecahan masalah-masalah matematis, sedangkan, banyak pengalaman kesuksesan mereka dalam menangani dan menyelesaikan masalah-masalah matematika, terutama masalahmasalah yang tidak rutin, dapat meningkatkan rasa percaya diri mereka dalam hal itu. Hal ini sejalan dengan pendapat Ubaedy (2011) yang mengatakan bahwa kesuksesan seseorang dalam melakukan sesuatu akan menumbuhkan rasa percaya dirinya dalam hal tersebut.

Sumarmo (1993), dalam studinya mengenai pemecahan masalah matematis siswa SLTP dan SLTA serta guru-guru matematika menemukan bahwa dalam tingkat berpikir formal, siswa SMU belum berkembang secara optimal dan kemampuan pemecahan masalahnya masih rendah.

Rendahnya kemampuan matematis siswa secara umum disebabkan oleh dua faktor, yaitu: (a) faktor internal; (b) faktor eksternal. Faktor internal salah satunya adalah pandangan siswa yang mengatakan bahwa matematika itu sulit, hal ini sering menjadikan mereka benci dan takut untuk belajar matematika. Kebencian dan ketakutan terhadap matematika merupakan dua unsure yang diakibatkan oleh tidak adanya rasa percaya diri (self-confidence) 


\section{Didaktik : J urnal Pendidikan Guru Sekolah Dasar, ISSN : 2477-5673 \\ Sekolah Tinggi Keguruan dan IImu Pendidikan Subang \\ Volume II Nomor 1, Desember 2016}

atas potensi yang mereka miliki.

Faktor eksternal salah satunya adalah cara guru dalam pembelajaran. Guru terbiasa melakukan pembelajaran konvensional, hanya sekedar menyampaikan pesan pengetahuan, sementara siswa cenderung pasif.

Salah satu model pembelajaran yang diasumsikan dapat meningkatkan kemampuan pemecahan masalah dan selfconfidence siswa adalah model pembelajaran Missouri Mathematics Project (MMP)

Model pembelajaran MMP memberikan kesempatan kepada siswa dan guru secara bersamasama proaktif dalam proses pembelajaran. Dengan menerapkan model pembelajaran MMP, guru bertindak sebagai fasilitator dalam pembelajaran, sedangkan siswa aktif dalam menemukan sendiri konsep matematika yang sedang dipelajarinya, sehingga konsep tersebut mudah dipahami dan bertahan lama dalam ingatan siswa dan siswa akan lebih mampu mentransfer pengetahuannya kedalam pemecahan masalah matematis. Setelah itu siswa secara kooperatif mengerjakan latihanlatihan kelompok, dimana didalamnya siswa saling membantu dalam menguasai bahan ajar, sehingga siswa akan lebih percaya diri untuk bertanya atau menyampaikan pendapatnya. Selanjutnya, dengan latihan mandiri, siswa dapat mengukur sejauh mana pengetahuan atau kepahaman yang mereka miliki tanpa bantuan orang lain. Pekerjaan rumah berupa soal-soal pemecahan masalah non rutin juga selalu diberikan, hal ini untuk memberi motivasi dan lebih meningkatkan kualitas pemahaman konsep matematis siswa secara maksimal.

Berdasarkan latar belakang yang telah dipaparkan, penulis tertarik untuk melakukan penelitian mengenai upaya meningkatkan kemampuan pemecahan masalah matematis dan self-confidence siswa Madrasah Tsanawiyah melalui model pembelajaran Missouri Mathematics Project (MMP).

Penelitian ini berfokus pada masalah: (1) Apakah peningkatan kemampuan pemecahan masalah matematis siswa MTs yang mendapat pembelajaran dengan model MMP lebih baik dibandingkan dengan 
siswa yang mendapat pembelajaran konvensional?

Apakah

peningkatan self-confidence siswa MTs yang mendapat pembelajaran dengan model MMP lebih baik dibandingkan dengan siswa yang mendapat pembelajaran

konvensional? dan (3) Bagaimana korelasi antara kemampuan pemecahan masalah matematis dan self-confidence baik siswa yang memperoleh pembelajaran model MMP maupun yang memperoleh pembelajaran konvensional?.

\section{B. METODE PENELITIAN}

Digunakan metode eksperimen dengan desain kelompok kontrol pretes-postes.

Penelitian dilaksanakan di MTs Negeri 1 Kabupaten Subang semester ganjil tahun ajaran 21012/2013 dengan populasi seluruh siswa kelas IX dan digunakan dua kelas sebagai sampel dari sejumlah kelas IX yang ada secara purposif.

Penelitian ini dilakukan dalam beberapa langkah, langkah pertama berkaitan dengan persiapan pembuatan instrumen penelitian dan bahan ajar. Langkah kedua adalah proses pelaksanaan penelitian, dengan tahapan memberikan soal pretes kepada siswa kelas eksperimen dan kelas kontrol, memberi pembelajaran dengan menggunakan model MMP untuk kelas eksperimen, sedangkan kelas kontrol pembelajaran konvensional, dan memberikan soal postes untuk kedua kelas. Langkah ketiga melakukan analisis peningkatan kemampuan pemecahan masalah dan self-confidence yang dicapai siswa kedua kelas, serta analisis korelasi antara kemampuan pemecahan masalah matematis dan self-confidence baik siswa yang memperoleh pembelajaran dengan model MMP maupun yang memperoleh pembelajaran konvensional. Teknik analisis data dilakukan atas data kuantitatif dan data kualitatif yang dikuantitatifkan Langkah keempat menyiapkan laporan hasil penelitian.

\section{HASIL DAN PEMBAHASAN}

Bagian hasil dan pembahasan ini dibagi menjadi tiga topik utama, yaitu: (1) Peningkatan kemampuan pemecahan masalah matematis siswa, (2) Peningkatan selfconfidence siswa, dan (3) Korelasi antara kemampuan pemecahan 
masalah matematis dengan selfconfidence siswa.

1. Peningkatan

Kemampuan Pemecahan Masalah Matematis Siswa

Peningkatan kemampuan pemecahan masalah matematis siswa dalam penelitian ini, dilihat dengan mengolah data hasil pretes, postes dan $\mathrm{N}$-gain. Pretes diberikan kepada kedua kelas untuk mengetahui bagaimana kemampuan awal pemecahan masalah siswa, sedangkan postes diberikan untuk mengetahui kemampuan akhir pemecahan masalah matematis siswaBerikut ini disajikan statistik deskriptif dari data hasil pretes dan postes

Tabel 1

Statistik Deskriptif Data Hasil Pretes \& Postes

\begin{tabular}{|l|c|r|r|}
\hline \multicolumn{2}{|c|}{} & $\begin{array}{c}\text { Statistik } \\
\text { Pretes }\end{array}$ & $\begin{array}{c}\text { Statistik } \\
\text { Postes }\end{array}$ \\
\hline \multirow{4}{*}{$\begin{array}{l}\text { Kelas } \\
\text { Eksperimen }\end{array}$} & $\mathrm{N}$ & 37 & 37 \\
\cline { 2 - 4 } & $X_{m}$ & 15 & 44.5 \\
\cline { 2 - 4 } & $X_{m}$ & 4 & 21.5 \\
\cline { 2 - 4 } & $\bar{X}$ & 8.6622 & 33.9459 \\
\hline $\begin{array}{l}\text { Kelas } \\
\text { Kontrol }\end{array}$ & $\mathrm{S}$ & 3.2082 & 5.7552 \\
\cline { 2 - 4 } & $X_{m}$ & 38 & 38 \\
\cline { 2 - 4 } & $X_{m}$ & 2.5 & 20.5 \\
\cline { 2 - 4 } & $\bar{X}$ & 7.7763 & 30.2632 \\
\cline { 2 - 4 } & $\mathrm{S}$ & 4.0448 & 4.6393 \\
\hline \multicolumn{2}{|l|}{$\begin{array}{l}\text { SkorMaksimal } \\
\text { Ideal }\end{array}$} & \multicolumn{3}{|c}{50} \\
\hline
\end{tabular}

Hasil uji normalitas data pretes disajikan dalam Tabel berikut.

Tabel 2 Hasil Uji Normalitas Data Pretes

\begin{tabular}{|c|c|c|c|}
\hline \multirow{2}{*}{ Kelas } & \multicolumn{3}{|c|}{$\begin{array}{c}\text { Kolmogorov- } \\
\text { Smirnov }\end{array}$} \\
\cline { 2 - 4 } & Statistic & Df. & Sig. \\
\hline Eksperimen & .141 & 37 & .059 \\
\hline Kontrol & .159 & 38 & .016 \\
\hline
\end{tabular}

Berdasarkan hasil uji normalitas data pretes kedua kelas, disimpulkan bahwa data hasil pretes kelas eksperimen berdistribusi normal (Sig.>0.05), sedangkan untuk data hasil pretes kelas kontrol tidak berdistribusi normal (Sig. <0.05). Oleh karena salah satu data hasil pretes tidak berdistribusi normal, maka analisis perbedaan kemampuan awal pemecahan masalah matematis kedua kelas menggunakan uji Mann-Whitney. Hasil uji Mann-Whitney disajikan dalam Tabel berikut.

Tabel 3 Hasil Uji Mann-Whitney

\begin{tabular}{|l|r|}
\hline & \multicolumn{1}{|c|}{ Statistik } \\
\hline Mann-Whitney U & 542.00 \\
$Z$ & 0 \\
$\begin{array}{l}\text { Asymp. Sig. (2- } \\
\text { tailed) }\end{array}$ & -1.713 \\
\hline
\end{tabular}


Berdasarkan Tabel 3, diperoleh nilai signifikansi 0.87 (> 0.05), artinya tidak terdapat perbedaan kemampuan awal pemecahan masalah pada kedua kelas.

Oleh karena hasil analisis data pretes menunjukkan bahwa kemampuan awal pemecahan masalah matematis siswa kedua kelas berada pada level yang sama, maka untuk melihat perbedaan peningkatan kemampuan tersebut digunakan data hasil postes, data $N$ gain hanya akan digunakan untuk memberikan gambaran tentang bagaimana mutu peningkatan kemampuan pemecahan masalah matematis siswa di kedua kelas.

Hasil uji normalitas data postes kedua kelas disajikan dalam tebel berikut.

\section{Tabel 4}

Hasil Uji Normalitas Data Postes

\begin{tabular}{|c|c|c|c|}
\hline \multirow{2}{*}{ Kelas } & \multicolumn{4}{|c|}{$\begin{array}{c}\text { Kolmogorov- } \\
\text { Smirnov }\end{array}$} \\
\cline { 2 - 4 } & Statistic & Df. & Sig. \\
\hline Eksperimen & .110 & 37 & .200 \\
\hline Kontrol & .080 & 38 & .200 \\
\hline
\end{tabular}

Berdasarkan Tabel 4,

disimpulkan bahwa data hasil postes kelas eksperimen dan kelas kontrol berdistribusi normal (Sig. >0.05),
Karena kedua jenis data berdistribusi normal, maka selanjutnya dilakukan uji homogenitas varians (Levene Statistic). Hasil Uji Homogenitas disajikan dalam Tabel berikut.

Tabel 5

Hasil Uji Homogenitas Varians Data Postes

\begin{tabular}{|c|c|c|c|c|}
\hline & $\begin{array}{l}\text { Levene } \\
\text { Statistic }\end{array}$ & $\mathrm{Df1}$ & Df2 & Sig. \\
\hline $\begin{array}{c}\text { Skor } \\
\text { Postes } \\
\text { Based } \\
\text { on } \\
\text { Mean }\end{array}$ & 1.382 & 1 & 73 & .244 \\
\hline
\end{tabular}

diperoleh sig. $=0.244>0.05$, sehingga varians kemampuan pemecahan masalah kedua kelas adalah homogen. Karena data homogen, uji statistik selanjutnya adalah uji t. Hasil uji t disajikan dalam Tabel berikut.

Tabel 6

Hasil Uji Perbedaan Dua Rerata Data Postes

\begin{tabular}{|l|l|l|l|}
\hline \multirow{2}{*}{} & \multicolumn{3}{|l|}{ t-test for Equality of Means } \\
\cline { 2 - 4 } & $\mathrm{T}$ & Df & $\begin{array}{l}\text { Sig. } \\
\text { tailed) }\end{array}$ \\
\hline $\begin{array}{l}\text { Skor } \\
\text { Postes }\end{array}$ & 3.055 & .003 & 3.68279 \\
\hline \multicolumn{3}{|c|}{ Hasil perhitungan uji t pada }
\end{tabular}

Tabel 6 diperoleh nilai sig. (1tailed $=0.0015<0.05$, sehingga terdapat perbedaan kemampuan pemecahan masalah matematis siswa pada kedua kelas. Artinya, siswa yang memperoleh pembelajaran matamatika dengan 
menggunakan model MMP memiliki kemampuan pemecahan masalah matematis yang lebih baik daripada siswa yang memperoleh pembelajaran konvensional. Hasil perhitungan $N$-gain disajikan dalam Tebel berikut.

Tabel 7

N-gain Kemampuan Pemecahan Masalah Matematis Siswa

\begin{tabular}{|c|c|c|c|}
\hline & $\mathrm{N}$ & $\begin{array}{c}\text { Rerata } \\
\text { N-gain }\end{array}$ & $\begin{array}{c}\text { Kualifikas } \\
\mathrm{i}\end{array}$ \\
\hline $\begin{array}{c}\text { Kelas } \\
\text { Eksperim } \\
\text { en }\end{array}$ & 37 & 0.6219 & Sedang \\
\hline $\begin{array}{c}\text { Kelas } \\
\text { Kontrol }\end{array}$ & 38 & 0.5299 & Sedang \\
\hline
\end{tabular}

\section{Peningkatan Self-Confidence} Siswa

Skala self-confidence awal diberikan kepada siswa dengan tujuan mengetahui self-confidence siswa pada kedua kelas sebelum pembelajaran, sedangkan skala selfconfidence akhir diberikan kepada siswa dengan tujuan mengetahui selfconfidence siswa pada kedua kelas setelah pembelajaran. Skala selfconfidence awal dan akhir ini digunakan untuk melihat peningkatan self-confidence siswa.

Berikut disajikan hasil uji normalitas skor angket awal SelfConfidence siswa pada kedua kelas.
Tabel 8

Hasil Uji Normalitas Skor Angket

Awal Self-C onfidence Siswa

\begin{tabular}{|l|l|l|r|}
\hline \multirow{2}{*}{ Kelas } & \multicolumn{3}{|c|}{ Kolmogorov-Smirnov } \\
\cline { 2 - 4 } & Statistic & Df & Sig. \\
\hline Eksperimen & .095 & 37 & .200 \\
\hline Kontrol & .147 & 38 & .037 \\
\hline \multicolumn{2}{|c|}{ Berdasarkan } & Tabel & 8 ,
\end{tabular}

diperoleh nilai signifikansi untuk kelas eksperimen adalah 0.20 (> 0.05), yang artinya data berdisribusi normal, sedangkan untuk kelas kontrol adalah 0.037 (< 0.05), yang artinya data tidak berdistribusi normal.

Karena salah satu data tidak berdistribusi normal, maka uji statistik selanjutnya yang digunakan untuk menentukan ada atau tidaknya perbedaan nilai rerata angket awal self-confidence adalah uji nonparametrik, yaitu uji Mann Whitney.

Hasil uji Mann-Whitney disajikan dalam Tabel berikut.

Tabel 9

Hasil Uji Perbedaan Dua Rerata

Angket Awal Self-Confidence

Siswa

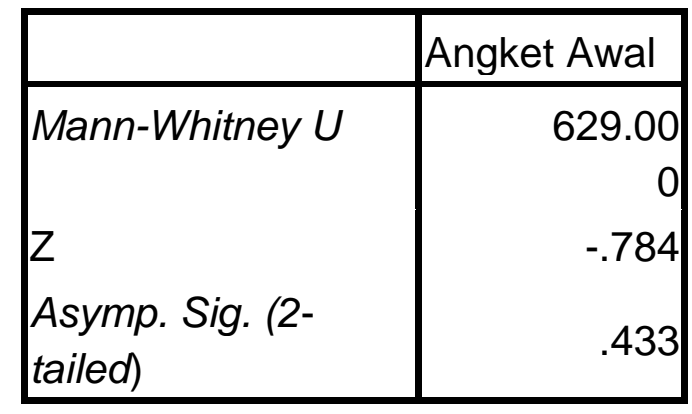

Berdasarkan Tabel 9, diketahui bahwa nilai signifikasi (sig.) sebesar 
0.43 (>0.05), sehingga dapat disimpulkan bahwa sebelum mendapatkan pembelajaran, siswa kedua kelas tersebut memiliki tingkat self-confidence yang sama.

Karena tingkat self-confidence awal kedua kelas berada pada level yang sama, maka, untuk mengetahui perbedaan peningkatan selfconfidence siswa kedua kelas tersebut, data yang akan dianalisis adalah data skor angket akhir selfconfidence. Skor $\mathrm{N}$-gain hanya akan digunakan untuk memberikan gambaran tentang bagaimana mutu peningkatan self-confidence siswa

Hasil uji normalitas data skor angket akhir self-confidence disajikan dalam Tabel berikut.

Tabel 10 Hasil Uji Normalitas Skor Angket Akhir Self-Confidence Siswa

\begin{tabular}{|l|l|l|l|}
\hline \multirow{2}{*}{ Kelas } & \multicolumn{3}{|l|}{ Kolmogorov-Smirnov } \\
\cline { 2 - 4 } & Statistic & Df & Sig. \\
\hline Eksperimen & .069 & 37 & .200 \\
\hline Kontrol & .148 & 38 & .034 \\
\hline
\end{tabular}

Berdasarkan Tabel 10, diperoleh nilai signifikansi (sig.) untuk kelas eksperimen sebesar 0.20 (> 0.05 ) yang artinya data berdistribusi normal, sedangkan untuk kelas kontrol adalah $0.034(<0.05)$, yang artinya data tidak berdistribusi normal. Karena salah satu data tidak berdistribusi normal, uji statistik selanjutnya yang digunakan untuk menentukan ada atau tidaknya perbedaan nilai rerata angket akhir self-confidence adalah uji nonparametrik, yaitu uji Mann Whitney. Hasil uji Mann-Whitney disajikan dalam Tabel berikut.

\section{Tabel 11}

Hasil Uji Perbedaan Dua Rerata

Angket Akhir Self-Confidence Siswa

\begin{tabular}{|l|r|}
\hline & Angket Akhir \\
\hline Mann-Whitney U & 87.000 \\
$Z$ & -6.528 \\
Asymp. Sig. (2- & .000 \\
tailed)
\end{tabular}

Berdasarkan Tabel 11, diketahui bahwa nilai signifikasi (2tailed) sebesar $0.00 \quad(<0.05)$, sehingga dapat disimpulkan bahwa rerata skor angket akhir selfconfidence siswa kelas eksperimen lebih tinggi daripada siswa yang memperoleh pembelajaran konvensional.

Secara rata-rata, kualifikasi peningkatan self-confidence disajikan dalam tebel berikut.

Tabel 12

$\mathrm{N}$-gain self-confidence Siswa

\begin{tabular}{|c|c|c|c|}
\hline & $\mathrm{N}$ & $\begin{array}{c}\text { Rerata } \\
\mathrm{N} \text {-gain }\end{array}$ & Kualifikasi \\
\hline $\begin{array}{c}\text { Kelas } \\
\text { Eksperim }\end{array}$ & 37 & 0.3432 & Sedang \\
\hline
\end{tabular}




\begin{tabular}{|c|c|c|c|}
\hline en & & & \\
\hline $\begin{array}{c}\text { Kelas } \\
\text { Kontrol }\end{array}$ & 38 & 0.0752 & Rendah \\
\hline
\end{tabular}

3. Korelasi antara kemampuan pemecahan masalah matematis dengan self-confidence siswa.

Bagian ini menganalisis hubungan antara kemampuan pemecahan masalah matematis dan self-confidence, baik siswa kelas eksperimen maupun siswa kelas kontrol. Untuk itu, dilakukan uji korelasi.

a. Uji korelasi kemampuan pemecahan masalah matematis dan self-confidence siswa kelas kontrol

Uji normalitas data postes kemampuan pemecahan masalah matematis dan angket akhir siswa kelas kontrol telah disajikan sebelumnya yang memperlihatkan bahwa skor postes kemampuan pemecahan masalah matematis siswa berdistribusi normal, sedangkan skor angket akhir selfconfidence siswa kelas kontrol tidak berdistribusi normal. Untuk mengetahui seberapa kuat hubungan antara kemampuan pemecahan masalah matematis dan self- confidence siswa dalam matematika, digunakan uji korelasi Rank Spearman. Hasil uji korelasinya disajikan dalam Tabel berikut.

Tabel 13

Hasil Uji Korelasi Kemampuan Pemecahan Masalah dan SelfConfidence Siswa Kelas Kontrol

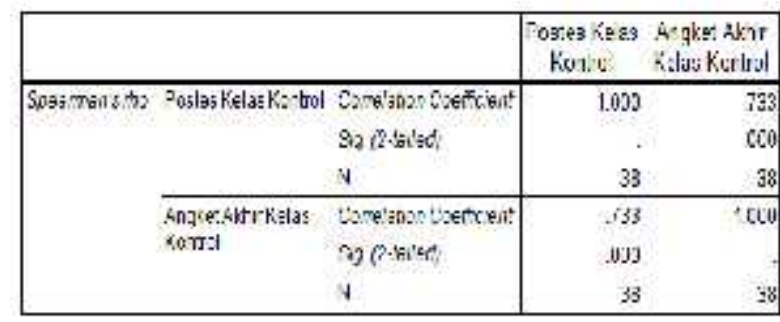

Tabel 13, memperlihatkan korelasi antara kemampuan pemecahan masalah matematis dan self-confidence siswa kelas kontrol adalah 0,733 dengan nilai signifikansi sebesar 0,00. Harga korelasi yang diperoleh adalah 0,733 yang berarti tingkat hubungannya tergolong tinggi. Karena nilai signifikansi 0,00 kurang dari 0,05, maka terdapat hubungan yang signifikan antara kemampuan pemecahan masalah matematis dan self-confidence siswa kelas kontrol.

b. Uji korelasi kemampuan pemecahan masalah matematis dan self-confidence siswa kelas eksperimen

Uji normalitas skor postes kemampuan pemecahan masalah matematis dan angket akhir siswa 
kelas eksperimenpun telah dilakukan pada pembahasan sebelumnya. Hasilnya memperlihatkan bahwa skor postes kemampuan pemecahan masalah matematis dan angket akhir self-confidence siswa kelas eksperimen berdistribusi normal, sehingga, untuk mengetahui seberapa kuat hubungan antara kemampuan pemecahan masalah matematis dan self-confidence siswa dalam matematika digunakan uji korelasi Product Moment Pearson. Hasil uji korelasinya disajikan dalam Tabel berikut.

Tabel 14

Hasil Uji Korelasi Kemampuan

Pemecahan Masalah dan SelfConfidence Siswa Kelas

\begin{tabular}{|c|c|c|c|}
\hline & & \begin{tabular}{|c|} 
Postes Kelas \\
Ekjpan nial
\end{tabular} & $\begin{array}{l}\text { Aroke: Akt } \\
\text { Ekspe inuzal }\end{array}$ \\
\hline \multirow[t]{3}{*}{ Posles Kelas Ekspermar } & Pearson Cxrelabon & & 773 \\
\hline & Sod 2 tait $(9 c)$ & & aco \\
\hline & $\mathrm{s}$ & Si & 37 \\
\hline \multirow{3}{*}{$\begin{array}{l}\text { Magoth hir <riat } \\
\text { Etajt:iltel }\end{array}$} & Frarme camplang & 773 & 7 \\
\hline & sia. $(1$-tented & ard & \\
\hline & & 21 & 21 \\
\hline
\end{tabular}

\section{Eksperimen}

Dari Tabel 14, diperoleh korelasi antara kemampuan pemecahan masalah matematis dan self-confidence siswa kelas eksperimen adalah 0,773 dengan nilai signifikansi sebesar 0,00 . Harga korelasi yang diperoleh adalah 0,773 yang berarti tingkat hubungannya tergolong tinggi. Karena nilai signifikansi 0,00 kurang dari 0,05 , maka terdapat hubungan positif yang signifikan antara kemampuan pemecahan masalah matematis dan self-confidence siswa kelas eksperimen.

\section{KESIMPULAN DAN SARAN}

Dari seluruh rangkaian penelitian yang telah dilakukan, mulai dari langkah persiapan, pelaksanaan, hingga analisis data, maka dapat dikemukaan kesimpulan sebagai berikut.

1. Peningkatan kemampuan pemecahan masalah matematis siswa MTs yang mendapat pembelajaran dengan model MMP lebih baik dibandingkan dengan siswa yang mendapat pembelajaran konvensional (ekspositori).

2. Peningkatan self-confidence siswa MTs yang mendapat pembelajaran dengan model MMP lebih baik dibandingkan dengan siswa yang mendapat pembelajaran konvensional (ekspositori).

3. Terdapat hubungan positif yang signifikan antara kemampuan pemecahan masalah matematis dan self-confidence siswa yang 


\section{Didaktik : J urnal Pendidikan Guru Sekolah Dasar, ISSN : 2477-5673 \\ Sekolah Tinggi Keguruan dan IImu Pendidikan Subang \\ Volume II Nomor 1, Desember 2016}

memperoleh pembelajaran MMP

maupun siswa yang memperoleh

pembelajaran konvensional.

Hasil penelitian ini memberikan sebuah alternatif upaya guru atau sekolah dalam meningkatkan kemampuan pemecahan masalah matematis dan self-confidence siswa. Apabila model ini akan dilakukan, sebaiknya dilakukan dalam waktu yang lebih lama. Selain itu, bagi peneliti lanjutan, hendaknya dilakukan dengan tambahan alat ukur yang lebih akurat dan pada kajian yang lebih luas, baik materi, populasi, maupun kemampuan matematika lainnya.

\section{DAFTAR PUSTAKA}

Bell, F. H. (1978). Teaching and Learning Mathematics (in secondary schools). United States: Brown Company Publisher.

Krulik, S. dan Rays, R. E.(1980). Problem Solving in School Mathematics. Virginia. NCTM.

Perry, M. (2006).Confidence Booster. Jakarta: Esensi.

Polya, G. (1985). How to Solve it. A new Aspect of Mathematical Method, Second Edition. New Jersey: Princenton University Press.

Suherman, E. dkk. (2003). Strategi Pembelajaran Matematika
Kontemporer. Bandung: JICAUPI.

Sumarmo, U. (1994). Suatu Alternatif Pengajaran untuk Meningkatkan Kemampuan Pemecahan Masalah pada Guru dan Siswa SMA di Kodya Bandung. Laporan Penelitian IKIP Bandung: Tidak Diterbitkan.

Sundayana, R. (2010). Statistika Penelitian Pendidikan. Garut: STKIP Garut Press.

Ubaedy, A.N. (2011). Total Confidence.9 Langkah Mendongkrak Pede. Bogor: Bee Media Pustaka.

Wahyudin.(2008). Pembelajaran dan Model-model Pembelajaran. Pelengkap untuk Meningkatkan Kompetensi Pedagogis Para Guru dan Calon Guru Profesional. Bandung: Tidak Diterbitkan. 